\title{
IFAS Community Development: The Importance of Local Community Action in Shaping Development 1
}

Mark A. Brennan ${ }^{2}$

This paper is part of a series of discussions on community development. This series will include specialized papers on civic engagement, community action, and other topics important to the development of community.

\section{Introduction}

The need for local participation and the organization of local residents to meet the challenges facing their communities is of increasing importance. Extension professionals and policy-makers are more frequently faced with the task of establishing programs in settings characterized by conflict among different groups of stakeholders with very different needs, values, and policy preferences. In many communities, these conflicts are often rooted to differences between groups that seek to protect community quality and those that seek to exploit local resources (especially the local workforce and natural resource base) as a means of achieving economic development. Equally common is the consistent transfer of responsibilities for services from government agencies to the private community sector. Such conditions have resulted in local residents taking on a greater role in providing services and planning for future needs. In response to the pressures and changes in our communities, activists, grassroots social change organizations, non-governmental organizations (NGOs), and coalitions of concerned community groups have emerged to shape and guide the development process. Similarly organized local residents have played instrumental roles in identifying new development options in localities that historically were presented with few such options. Community-based action in these and other settings is seen as essential to community development and to the social and economic well-being of the locale.

\section{Community and the Action Process}

The emergence of community involves both interaction among residents and community action. Community action refers to the process of building social relationships in pursuit of common community interests and maintaining local life (Wilkinson, 1991). Community action is seen as being the foundation of the community development process because it encompasses deliberate and positive efforts

1. This document is FCS 9209, of a series of the Department of Family, Youth and Community Sciences, Cooperative Extension Service, Institute of Food and Agricultural Sciences, University of Florida. Reviewed by A.E. Luloff, PhD, Department of Rural Sociology, Penn State University, University Park, PA and C. Flint, PhD, Penn State University, University Park, PA. Publication date: March 2005. Please visit the EDIS website at http://edis.ifas.ufl.edu

2. Mark A. Brennan, Assistant Professor of Community Development, Department of Family, Youth and Community Sciences, Cooperative Extension Service, Institute of Food and Agricultural Sciences, University of Florida, Gainesville, FL, 32611. 
designed to meet the general needs of all local residents. This process represents multiple and diverse interests in the locality, and consequently provides a more comprehensive approach to community development (Wilkinson, 1991). Therefore, the action process is intended to benefit the entire community and to cut across divides that may exist (class, race, social).

In the process of community development, local action focuses on the improvement of social well-being and involves people working together in pursuit of their general interests. This power is manifested in the ability of individuals to come together and work toward common goals. When diverse individuals and their organizations interact with one another, they begin to mutually understand the needs and wants that are common to all residents (Wilkinson, 1991; Luloff and Swanson, 1995). Such action provides local residents with the ability to retain community identities, maintain local control over decision-making, and address their own development needs. It is a central component of community and social well-being.

The existence of community action directs attention to the fact that local people acting together often have the power to transform and change their community (Gaventa, 1980; Luloff and Swanson, 1995). Community action and corresponding development can be seen as the process of building relationships that increase the adaptive capacity of local people within a common territory. This adaptive capacity is reflected in the ability of people to manage, utilize, and enhance those resources available to them in addressing their local issues (Luloff, 1990; Wilkinson, 1991; Luloff and Swanson, 1995; Luloff and Bridger, 2003). As long as people care about each other and the place they live, every community has the potential for such collective action. This ability allows distinctions to be made between simple aggregates of people and actual communities.

\section{The Community Action Process}

To impact social well being, community action must seek the development of community, not simply the individual elements within it (Summers, 1986; Christenson and Robinson, 1989; Wilkinson, 1991).
The community action process can be seen as containing far more than simple individual actions and efforts (Wilkinson, 1991). Most effective action efforts proceed through a series of steps that focus on solving specific problems and bringing residents closer together. Five stages of accomplishment, including initiation, organization of sponsorship, goal setting, recruitment, and implementation, can be identified within this process (Wilkinson, 1970; Wilkinson, 1991):

1.The first stage, initiation, focuses on promoting awareness of the issue related to the action. Initiation and spread of interest occurs when community members recognize and define an issue as being a problem or need, and begin to discuss it as a potential focus for group action.

2.The second stage focuses on the organization of sponsorship. This step addresses the structures, organizations, and resources available within and outside of the community. Such factors are important in relation to assessing community needs and the development of action efforts to address perceived problems.

3.The third stage is goal setting and strategy development. This stage develops targets for action and identifies strategies for achieving community decided goals.

4.The fourth stage is recruitment and mobilization of needed resources including people, money, and materials. Community members possess a variety of experience, skills, funding, materials, networks, and other resources vital to achieving desired community goals. Organizing and maximizing these resources significantly impacts the success of community action efforts.

5.The final stage involves the application of these resources in the implementation of plans to achieve the desired goals. At this stage, specific actions are taken, assessed, adjusted, and implemented again. 


\section{Conclusion}

Community action and the emergence of community should not be seen as representing romantic or idealized notions of local harmony and solidarity (Wilkinson, 1991; Luloff and Swanson, 1995; Luloff and Bridger, 2003). The truth is that focused and deliberate action represents something far different. Action emerges out of interaction between diverse social groups, who often have clashing or at least distinctly different points of view. Interaction facilitates the coming together of such groups to assess their common and general needs. From this they form plans for action that benefit all involved, and ultimately the community in general.

The importance of organizing diverse local residents to help shape local development cannot be overstated. By providing a comprehensive assessment of local conditions that represents all segments of the community, more efficient and successful programs can be developed. The input and guidance from local residents allows development to build on the unique conditions and character of the community and allow local decision making to remain in the locale. All of these create an environment where active local residents directly shape the community and its well-being.

\section{References}

Christenson, J. A. and J. W. Robinson. 1989. Community Development in Perspective. Ames, IA: Iowa State University Press.

Gaventa, J. 1980. Power and Powerlessness: Quiescence and Rebellion in an Appalachian Valley. Urbana, IL: University of Illinois Press.

Luloff, A.E. 1990. "Community and Social Change: How Do Small Communities Act?” Pp. 214-227 in A.E. Luloff and L.E. Swanson (ed.), American Rural Communities. Boulder, CO: Westview Press.

Luloff, A.E., and J. Bridger. 2003. Community Agency and Local Development. Pp. 203-213 in, Challenges for Rural America in the Twenty-First Century, edited by D. Brown and L. Swanson. University Park, PA: Pennsylvania State University Press.
Luloff, A. E. and L. Swanson. 1995. "Community Agency and Disaffection: Enhancing Collective Resources." Pp. 351-372 in Investing in People: The Human Capital Needs of Rural America, edited by L. Beaulieu and D. Mulkey. Boulder, CO: Westview Press.

Summers, G. 1986. "Rural Community Development." Annual Review of Sociology. 12:341-371.

Wilkinson, K. 1970. "Phases and roles in community action.” Rural Sociology. 35 (1): 54-68.

Wilkinson, K.P. 1991. The Community in Rural America. New York, NY: Greenwood Press, 1991.

\section{Suggested Reading}

Bridger J. and A.E. Luloff. 1999. "Toward an Interactional Approach to Sustainable Community Development". Journal of Rural Studies. 15:377-387.

Civic Practices Network. http://www.cpn.org/

Community Development Institute East. http://www.ext.wvu.edu/cdi-east/

The Community Development Society. http://www.comm-dev.org/

Community Resource Group. http://www.crg.org/

Community Tool Box. http://ctb.ku.edu/

Grass-roots.org. http://www.grass-roots.org/

International Association for Community

Development. http://www.iacdglobal.org/

Southern Rural Development Center. http://srdc.msstate.edu

Sustainable Development Communication Network. http://www.sdgateway.net 